\title{
MODEL PEMBELAJARAN SEKOLAH PEDULI ANAK HEBAT (SPAH) BAGI SISWA PENYANDANG DISABILITAS
}

\author{
Normalia Sage \\ SMA Muhammadiyah 10 Surabaya, Kota Surabaya, Jawa Timur \\ Email: pureza.sage@gmail.com
}

\begin{abstract}
Abstrak
Pemerintah mencanangkan pendidikan inklusif sesuai Permendiknas Nomor 70 tahun 2009. Siswa penyandang disabilitas dapat belajar di sekolah umum. Pendidikan inklusif menghadapi tantangan diantaranya kompetensi guru, sumber kurikulum yang kurang dan orang tua yang kurang puas, sehingga pendidikan inklusif berkembang sesuai dengan gaya dan kemampuan masing-masing lembaga. Ada yang lebih berfokus pada peningkatan skill kerja siswa penyandang disabilitas, ada juga yang meningkatkan kemampuan akademik sesuai kebutuhan mereka. Tulisan ini memaparkan pengembangan suatu inovasi pembelajaran inklusif alternatif yang berbasis passion siswa penyandang disabilitas di SMA. Sistem pendidikan yang dikembangkan ini fleksibel mengikuti bakat dan minat siswa dengan nama model pembelajaran Sekolah Peduli Anak Hebat (SPAH). SPAH memiliki lima model pembelajaran yakni Religious-Emotional-Social-HealthSupporting (RESHES); Sport-Art-Entrepreneur (SAE); Career Class (CC); Fun Academic (FA); dan Parent Society (PS) yang 50\% berfokus pada peningkatan potensi hati dan $30 \%$ potensi fisik dan $20 \%$ potensi akal pada pengembangan bakat-minat, karakter dan akademik anak hebat.
\end{abstract}

Kata kunci: inklusif, anak hebat, SPAH, hati, bakat.

\section{Pendahuluan}

Hampir satu abad pendidikan anak penyandang disabilitas berada dalam institusi yang terpisah dengan sekolah umum dimana mereka mendapatkan hak yang lebih sedikit dibandingkan anak pada umumnya. Indonesia mulai mendukung hak pendidikan dan sosial penyandang disabilitas melalui pendidikan inklusif. Sistem ini mulai diupayakan dengan baik oleh pemerintah sejak dikeluarkan Permendiknas No. 70 Tahun 2009 tentang Pendidikan Inklusif bagi Peserta Didik yang Memiliki Kelainan dan Memiliki Potensi Kecerdasan dan/atau Bakat Istimewa. Pendidikan inklusif ini secara jelas menghilangkan garis pembatas antara kelas regular dan kelas khusus, menyediakan pendidikan yang sesuai untuk semua siswa dengan level kognitif yang berbeda. Diharapkan dengan semakin banyaknya sekolah inklusif di tingkat SMA dapat menjadikan siswa penyandang disabilitas mampu mengenyam pendidikan melebihi wajib belajar sembilan tahun sebagaimana tertera dalam UU No. 23 tahun 2002 pasal 48 dan kesempatan memperoleh pendidikan yang seluasluasnya pada pasal 49, sehingga mereka dapat lebih siap untuk memasuki dunia kerja atau perguruan tinggi. Sekarang ini bukan saatnya lagi ada diskriminasi bagi masyarakat penyandang disabilitas. Pelayanan publik, mulai transportasi, pasar, rumah makan sampai sekolah pun mulai dikembangkan ke arah fasilitas dan pelayanan yang ramah bagi mereka. 
Selama pendidikan inklusif berfungsi untuk mendapatkan keadilan sosial atau menghilangkan sikap diskriminasi terhadap siswa penyandang disabilitas, maka akan dapat digali manfaat yang lebih banyak di dalamnya. Seperti ketika siswa penyandang disabilitas berada di lingkungan sekolah umum, mau tidak mau mereka pun menjadi tergabung di dalam komunitas lokal. Adanya pendidikan inklusif memungkinkan mereka untuk berbaur dengan teman-teman yang sering mereka temui di sekolah dan bepergian bersama saat libur akhir pekan. Siswa penyandang disabilitas juga akan memiliki teman sebaya dari kelas reguler yang dapat menjadi model dalam mengambil sikap, perilaku, pengambilan keputusan, penyelesaian masalah dan keterampilan kognitif lain dalam skala kelompok (Will \& Jackson, 2000). Selain itu pendidikan inklusif juga membuat siswa reguler lebih toleran dan memahami kondisi kawan penyandang disabilitas yang juga memiliki kesamaan dengan dirinya. (Westwood \& Graham, 2003).

Di samping memiliki manfaat, pendidikan inklusif juga menyimpan berbagai tantangan. Kondisi mental dan fisik siswa penyandang disabilitas masih dipandang kurang memberikan kontribusi bagi kemajuan profil akademik sekolah bila dibandingkan dengan anak yang berprestasi (Konza, 2002). Untuk siswa penyandang disabilitas yang berat, guru umum cenderung nyaman dengan konsep integratif yang mana siswa penyandang disabilitas tidak sepenuhnya berada di kelas reguler, tetapi pada waktu tertentu mendapatkan pelayanan pendidikan secara individual bersama guru pembimbing khusus (Bowman, 1986). Mereka juga merasa kurang kompeten untuk menangani siswa penyandang disabilitas (Center and Ward, 1987). Guru juga mengaku tidak punya waktu untuk membuat material pembelajaran khusus bagi mereka ataupun modifikasi kurikulum, terutama dalam kelas besar - jumlah siswa diatas 30 (Schumm \& Vaughn, 1992).

Pendidikan inklusif di tingkat pendidikan dasar dan menengah berkembang sesuai gaya dan kemampuan masing-masing lembaga. Ada yang berfokus pada penyiapan skill kerja siswa penyandang disabilitas, dan ada pula yang berfokus pada peningkatan akademik sesuai dengan kebutuhan dan kemampuan mereka. Pada artikel ini akan dijelaskan suatu inovasi pengembangan model pembelajaran inklusif yang berbasis pada passion siswa penyandang disabilitas. Sebuah sistem pendidikan yang fleksible mengikuti bakat dan minat mereka, bukan memaksa mereka untuk mengikuti sistem yang ditetapkan sekolah.

Tulisan ini mereview upaya-upaya yang telah dilakukan sebuah sekolah swasta di Surabaya dalam meningkatkan pendidikan bagi siswa penyandang disabilitas, yang dalam tulisan ini selanjutnya disebut anak hebat, di tingkat SMA. Tulisan ini menggambarkan secara singkat praktik lima model pembelajaran pada sekolah inklusif dalam memfasilitasi anak penyandang disabilitas dapat mengembangkan karakter, pengetahuan, skill terutama kepercayaan diri mereka. agar dapat sukses di universitas, karier dan kehidupan bermasyarakat.

\section{Konteks Studi: Pendidikan Inklusif di SMA Muhammadiyah 10 Surabaya}

Tulisan ini menggambarkan pendidikan inklusif yang diselenggarakan oleh SMA Muhammadiyah 10 Surabaya (SMAM X). SMAM X Surabaya merupakan sebuah sekolah keberbakatan Sport, Art and Science (Spartan) mengembangkan 
program inklusif berbasis passion siswa penyandang disabilitas dengan nama Sekolah Peduli Anak Hebat (SPAH) sebagai bentuk diferensiasi yang ke enam. Hal yang mendasari pendirian program SPAH adalah komitmen menerima siswa dalam kondisi apapun. Sejak berdirinya pada tahun 2014 sekolah telah menerima siswa penyandang disabilitas dalam tingkatan apapun tanpa seleksi. Sekolah berprinsip siswa penyandang disabilitas juga memiliki hak yang sama untuk mendapatkan kualitas pendidikan dan sukses sama dengan siswa yang lain.

SMAM X Surabaya dengan jumlah siswa mencapai 709 memiliki 30 siswa penyandang disabilitas dari tahun 20142018 (lihat gambar 1) dan telah meluluskan empat siswa penyandang disabilitas yang saat ini telah melanjutkan studi ke perguruan tinggi.

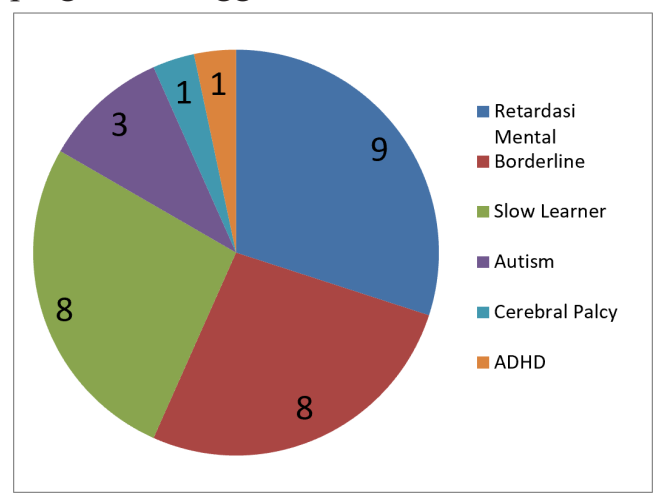

Gambar 1. Data Jumlah Anak Hebat SMAM X Surabaya 2014-2018

Sekolah memastikan bahwa anak-anak penyandang disabilitas memiliki hak untuk mendapatkan pendidikan yang baik dan kesuksesan di masa yang akan datang. Anak penyandang disabilitas anak tidak terbatas atau anak hebat. SPAH tidak hanya memberi kesempatan anak tidak terbatas dalam hal pencapaian kemampuan akademik khusus, namun juga pada pembentukan karakter, kemampuan sosialisasi, pengembangan bakat dan minat serta pendampingan karier berkelanjutan, bagi mereka yang ingin melanjutkan kuliah atau terjun di dunia kerja. Sekolah memiliki guru PLB, terapis, psikolog dan dokter profesional SPAH yang juga memfasilitasi konsultasi bagi masyarakat sekitar yang ingin tahu atau berpartisipasi dalam pendidikan inklusi. Hal ini dilakukan supaya semakin tumbuh sikap kepedulian masyarakat terhadap anak tidak terbatas. Program ini terangkum dalam lima model pembelajaran SPAH, yakni ReligiusEmotional-Social-Health-Supporting (RESHES), Sport-Art-Entrepreneur (SAE), Career Class (CC), Fun Academic (FA) dan Parent-Society (PS).

\section{LIMA MODEL PEMBELAJARAN SPAH}

Model pembelajaran Sekolah Peduli Anak Hebat (SPAH) berupa praktik pembelajaran anak hebat yang terbagi menjadi dua sistem yakni sistem integratif dan fullinclusion. Pertama, integratif adalah sistem yang memungkinkan anak hebat belajar di kelas khusus pada sekolah reguler, namun pada bidang-bidang tertentu dapat belajar bersama anak lain di kelas reguler. Dalam hal ini SMAM X Surabaya berkomitmen bahwa semua calon siswa penyandang disabilitas akan diterima tanpa seleksi. Untuk siswa dengan tingkat ketunaan yang sedang ke berat, seperti autis dan retardasi mental dengan gangguan psikomotorik lebih tepat menggunakan sistem integratif ini sebagaimana hasil penelitian Mc. Leskey dan Waldron (2011) pada siswa SD menunjukkan anak dengan tingkatan disabilitas yang berat terutama dalam ranah kognitif lebih efektif dengan metode integratif, karena di kelas khusus mereka mendapatkan pengajaran yang lebih intensif, konsep dan skill yang mereka butuhkan. Kedua, full-inclusion yakni sistem yang menyertakan anak hebat 
untuk menerima pembelajaran individual/ kelompok dalam kelas reguler. Anak hebat dengan tipe slow learner/lambat belajar yang mengikuti sistem ini dengan model kurikulum yang diturunkan bobotnya atau siswa tuna daksa, rungu atau netra yang memiliki intelegensi normal ke atas.

Model pembelajaran SPAH berpijak pada tiga tatanan. Pertama, model ini lebih mengembangkan potensi hati daripada potensi akal dengan perbandingan persentase potensi hati, fisik dan akal sebesar $50: 30: 20$. Persentase ini menunjukkan tingkatan perhatian dan tahapan dalam program SPAH. Potensi hati terwujud dalam program Religius Emotional Social Health Suppoting (RESHES). Program ini mendapat perhatian jauh lebih besar dibanding yang lain, karena masalah terbesar anak hebat adalah pada tekanan psikologis, bukan transfer skill atau pengetahuan. Tekanan psikologis yang berasal dari dalam diri dan lingkungan ini menghambat mereka untuk dapat mengembangkan diri dan berprestasi. Dalam hal ini konseling formal, nonformal, individu atau kelompok dilakukan setiap hari, tanpa batas waktu dan media, sehingga terjalin kedekatan antara anak hebat dengan Guru Pembimbing Khusus (GPK). Jadi target awal 50\% adalah mengarahkan program bagaimana membuat anak menjadi percaya diri. Perhatian $30 \%$ potensi fisik berupa program bakat di sekolah yang diminati siswa bertajuk Sport, Art and entrepreneur (SAE) and Career Class (CC). SPAH SMAM X lebih berfokus pada kegiatan pembelajaran yang melibatkan aksi. Untuk memunculkan kepercayaan diri, kecakapan mengatasi masalah dan sosialisasi, anak diarahkan untuk mengikuti kegiatan potensi, komunitas dan lomba sesuai passion mereka bersama siswa regular. Perhatian $20 \%$ potensi akal adalah yang paling kecil dengan maksud bahwa program SPAH tidak berfokus pada peningkatan nilai akademik mata pelajaran. Pembelajaran diwujudkan dalam bentuk fun academic (FA). FA memberikan porsi perhatian dan waktu yang lebih pada materi yang berhubungan dengan kelebihan/potensi menonjol pada diri anak penyandang disabilitas. Jadwal, materi bisa jadi berbeda antara satu anak dengan yang lain.

\section{Penjabaran Lima Model Pembelajaran SPAH Adalah Sebagaimana Berikut.}

\section{Religius-Emotional-Social and Health Supporting (RESHES)-SPAH.}

Salah satu tantangan bagi guru dalam mengajar anak penyandang disabilitas adalah menguatkan mental dalam menghadapi hidup dan percaya diri dalam menatap masa depan. Sebagaimana dalam penelitian Turner dalam Smith (2012) memperlihatkan bahwa anak penyandang disabilitas terutama keterbelakangan mental memiliki kebutuhan untuk merasa menjadi bagian dari yang lain, kebutuhan untuk menemukan perlindungan dari sikap dan label negatif, kebutuhan akan dukungan dan kenyamanan sosial, kebutuhan untuk menghilangkan kebosanan dan menemukan stimulasi sosial. Dalam hal ini RESHES program berupaya membantu siswa penyandang disabilitas melalui empat langkah berikut ini.

(1) Kedekatan Guru. Dalam program SPAH, kedekatan antara guru dan siswa adalah hal yang utama. Hal ini menjadikan pelayanan individual siswa menjadi suatu keharusan. Di SMAM X Surabaya terdapat dua guru bagi Anak Hebat, yaitu guru reguler dan guru shadow/ pembimbing khusus. Guru pembimbing khusus (GPK)/shadow menjadi guru yang bertanggungjawab terhadap perkembangan anak hebat. Mulai perkembangan kognitif, 
afektif dan motorik mereka. Profesionalitas dalam pelayanan terlihat tatkala guru pembimbing khusus membawa maksimal lima anak hebat dengan tipe yang slow learner dan satu anak hebat dengan tipe autism.

Guru reguler ini telah dipersiapkan mindset dan sikapnya melalui orientasi kepala sekolah yang terus-menerus, penyuluhan dari tenaga ahli dan perilaku sosial antar guru untuk selalu menyapa anak hebat dan memperlakukan mereka dengan penuh kasih sayang/no bullying di dalam kelas maupun di luar kelas. Guru junior belajar dari perilaku guru senior dalam memperlakukan anak hebat. Hal ini juga menjadi contoh/teladan bagi siswa regular untuk bersikap yang sama terhadap Anak Hebat. Kedekatan ini terbentuk tidak berbatas interaksi di kelas tetapi dapat berlanjut di pertemuan informal ataupun sosmed. Guru pembimbing khusus membuat grup WA/Line untuk berkonsultasi dan memotivasi anak hebat di setiap harinya baik terkait materi religius, emosional maupun sosial.

(2) Guardian Angel (GA). Suatu kenyataan bahwa adaptasi anak hebat dan siswa regular tidaklah selalu berjalan mulus, semua butuh waktu dan proses. Anak hebat harus selalu dikuatkan untuk menghadapi kemungkinan bullying. Adanya Guardian Angel (GA) sebuah istilah untuk beberapa siswa regular pilihan di kelas inklusif yang bertugas untuk membantu anak hebat ini dalam berinteraksi sosial dengan yang lain. Model pembelajaran sosial ini dikenal dengan istilah Peer-Mediated Instruction and Interventions (PMII) yang menggunakan siswa lain sebagai instructor untuk anak hebat dalam pengawasan guru. Teman sebaya yang diistilahkan $G A$ dapat membimbing secara langsung ataupun tidak langsung melalui modeling dan guru hanya bersifat sebagai fasilitator. Instruksi dari $G A$ ini tidak hanya tentang materi akademik, tetapi juga perkembangan sosial dan emosional anak hebat (Kalfus, 1984). Para $G A$ ini memang dipilih dari siswa yang memiliki sifat baik, sabar, penuh kasih sayang, tulus, ramah dan bersahabat yang terpenting tidak ada pemaksaan dan ia mau untuk bersahabat dengan anak hebat. Selain waktu belajar bersama di kelas inklusi, waktu istirahat, sholat berjamaah dan makan bersama menjadi $100 \%$ waktu yang berharga bagi anak hebat untuk bersosialisasi, menjalin persahabatan dengan siswa reguler. Para $G A$ dan guru secara berkala juga mendapat penyuluhan dari tenaga ahli PSLD UNESA, di antaranya kegiatannya adalah nonton bareng film disabilitas, sharing together, game kolaborasi dengan anak hebat.

(3) Komunitas Anak Hebat. Era remaja generasi $\mathrm{Z}$ memang menyukai komunitas. Anak hebat ini dengan sendirinya membuat komunitas dalam grup sosial media untuk memperoleh informasi dan berbagai banyak hal antar teman. Guru pembimbing khusus tidak hanya guru di kelas tetapi ia dapat menjadi guru bagi mereka di manapun dan kapanpun. Ketelatenan dan kemauan seorang guru pembimbing khusus untuk menjawab pertanyaan mereka dan memotivasi mereka merupakan bagian dari program RESHES SPAH.

(4) Asesmen SPAH dari tenaga ahli. Asesmen menjadi alat penting untuk menempatkan anak hebat pada kelas integratif atau full inclusion, mengetahui fasilitas spesifik pendukung apa saja yang diperlukan dalam pembelajaran mereka, menempatkan mereka pada ekskul, potensi atau tempat magang yang sesuai dengan kemampuan dan passion mereka. Jalur proses asesmen dapat dilihat pada gambar 2. 


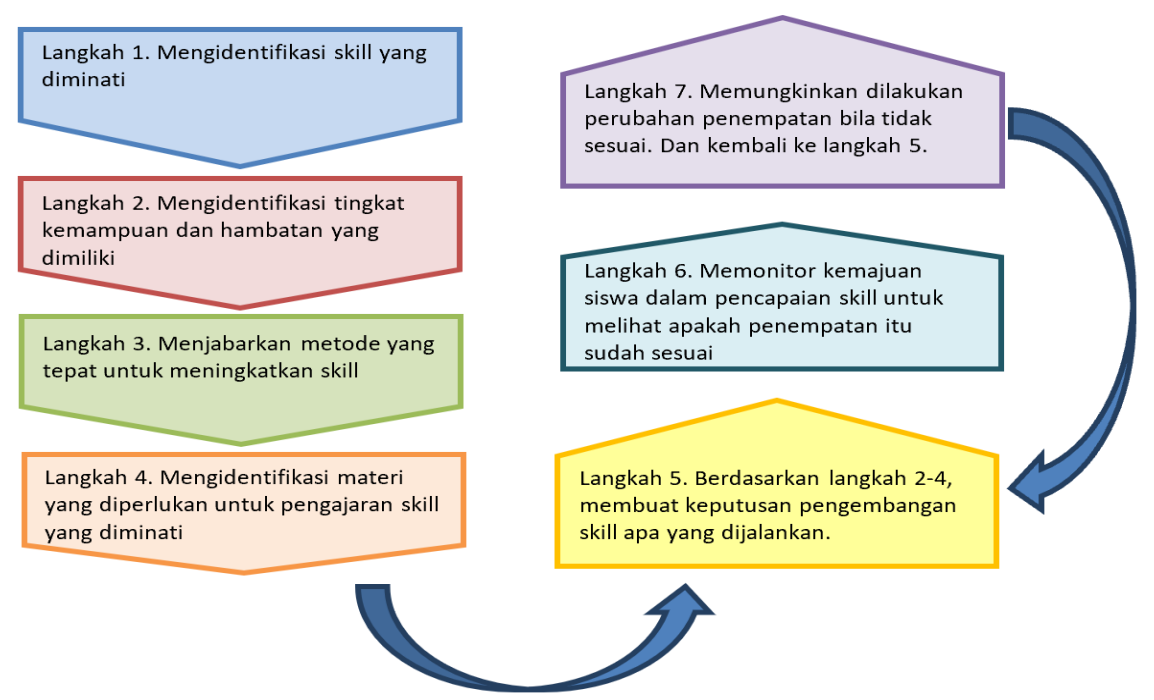

Gambar 2. Jalur Proses Assesmen dan Penempatan Bakat-Minat Anak Hebat

Berikut ini tahapan assesmen:

- Asesmen diagnostik tentang ketunaan dan tingkatannya bekerjasama dengan fakultas psikologi UNAIR.

- Asesmen bakat-minat oleh tim potensi psikologi SMAM X Surabaya melalui observasi, konsultasi dengan orang tua dan konseling individu

- Asesmen kesehatan bekerjasama dengan Rumah Sakit Muhammadiyah Surabaya yang memiliki poliklinik tersendiri di gedung SMAM X Surabaya. Cek kesehatan tersebut meliputi tanda utama, status gizi, cek visual, THT, motorik dan sakit fisik yang diderita anak hebat.

- Asesmen ahli terapis dilakukan setiap akhir semester untuk memberikan evaluasi perkembangan dan perbaikan metode pembelajaran dan terapi untuk peningkatan outcome anak hebat.

\section{Sport, Art, and Entrepreneur (SAE) SPAH}

Program SPAH lebih menitik beratkan kemampuan seni, olahraga dan life skill daripada nilai akademik anak hebat.
Model pembelajaran SAE ini berfungsi memfasilitasi bakat minat anak hebat, pembentukan karakter kepercayaan diri dan kebutuhan sosial menjadi bagian dari komunitas. Guru ekskul/potensi lebih menekankan pada sikap positif dalam belajar seperti berdoa sebelum latihan, cara menghargai kemampuan bakat teman yang beragam, menguatkan kepercayaan diri dan keyakinan dalam pengambilan keputusan. Bakat seni ini akan ditampilkan pada acara tertentu dan tentunya mereka juga berkolaborasi dengan siswa reguler dalam performa tersebut.

\section{Career Class (CC) SPAH}

Remaja dengan terbelakang mental hanya $2,5 \%$ yang mendaftar di perguruan tinggi setelah SMA dan lebih banyak yang belum sepenuhnya mandiri, sehingga SPAH melalui program career class menyiapkan anak hebat dengan life skill untuk bisa mandiri melalui magang dan transision planning. National Longitudinal Transition Study of Special Eduction (NLTS) U.S. dalam Smith (2012) menemukan bahwa rentang waktu yang lebih lama berada di pendidikan umum dan pengalaman 
kerja/magang di sekolah menengah dan pelatihan kejuruan selama di sekolah menengah lebih meningkatkan ketertarikan penerima lowongan pekerjaan pada siswa penyandang hambatan.

Magang sesuai passion. Hal yang terlihat berbeda dari sekolah inklusif lain adalah jadwal pembelajaran SPAH tidak bersifat kaku dan sangat fleksibel bagi anak hebat. Misalkan bila pada asesmen awal anak menginginkan untuk belajar pada bidang otomotif, maka dimungkinkan anak diarahkan untuk magang selama satu bulan di bengkel. Dengan demikian pembelajaran akademik dapat dilakukan setelahnya dengan pemberian contextual homework. Untuk anak hebat materi disesuaikan dengan kemampuan mereka. Semisal anak hebat dengan tipe tunagrahita diberikan bagian kerja mengganti busi, menambal ban. Dalam hal ini sekolah terus membuka kerjasama dengan berbagai lembaga atau perusahaan yang dapat menerima mereka untuk magang berdasarkan asesmen dan passion mereka. Selama magang perkembangan, kemajuan dan hambatan juga berada dalam rekap guru pendamping khusus melalui wawancara atau draf observasi yang diberikan pada guru tamu/pemilik tempat magang. Setiap anak yang telah mengikuti magang akan mendapatkan sertifikat yang kelak dapat digunakan sebagai bahan referensi ketika melamar suatu pekerjaan.

\section{Transition Planning}

Kelas transition planning diperuntukkan anak hebat kelas XII yang ingin melanjutkan ke universitas. SPAH memberikan pelayanan pendampingan tidak hanya sebatas ketika anak hebat lulus SMA, tetapi berkelanjutan sampai anak hebat ini benar-benar bisa beradaptasi di perguruan tinggi yang dituju.
Beberapa materi pada career class: Persiapan UNBK, Menjelaskan perbedaan aturan antara di SMA dan Universitas; Memberikan saran supaya sukses di universitas; Perencanaan dokumentasi kesehatan lebih awal; Membuat link informasi untuk orang tua dan wali; Menginformasikan link online untuk transisi ke universitas.

\section{Fun Academic (FA) SPAH}

Pemerintah mendukung pendidikan inklusif dengan harapan adanya kenaikan performa dari siswa penyandang disabilitas. Beberapa hasil penelitian menunjukkan praktik inklusif lebih besar keberhasilannya di tingkat sekolah dasar daripada menengah (Casale-Goannola dalam Ford, 2013), karenanya SPAH SMAM X Surabaya tidak menjadikan performa akademik menjadi kunci utama keberhasilan anak hebat. Pembelajaran akademik menjadi sarana untuk membentuk kedekatan guru dan anak hebat, tempat bersosialisasi dan membentuk karakter positif melalui aktivitas belajar bersama siswa reguler. Tempat meningkatkan kepercayaan diri tatkala berhasil menguasai suatu mata pelajaran yang telah dimodifikasi. Karena SPAH lebih concern ke pembentukan karakter atau potensi hati, maka terdapat beberapa acuan penting di fun academic, yakni:

- Pembelajaran akademik bersifat fleksibel dimulai dari yang mudah dan meningkat seiring kemampuan anak. Sehingga anak dapat menyelesaikan soal dengan kesalahan sedikit dan mendapat nilai yang tinggi dan sekaligus mendapatkan tantangan dengan peningkatan level sesuai kemampuan mereka.

- Proses pembelajaran akademik bersifat menyenangkan dengan mengaktifkan selain potensi akal juga fisik dan hati. 
Setiap anak berhasil harus diberikan reward baik dengan pujian, tepuk tangan, senyuman atau sentuhan dan sama sekali tidak diperkenankan memberikan hukuman. Contoh metode yang digunakan dalam pembelajaran, metode one short instruction, differentiated instruction, co-teaching, short-contextual homework, class wide peer tutorial dan juga terapi sesuai kebutuhan, seperti occupation, play, paint, water, compensatory therapy.

- Pembelajaran akademik bersifat kontekstual yakni mendekati permasalahan kongkrit di dunia nyata, sehingga mereka dapat mengaplikasikannya dalam kehidupan sehari-hari.

- Hasil evaluasi berisi deskripsi perkembangan belajar anak hebat dengan penilaian yang bersifat autentik dan holistik.

Gambar 3. Contoh Lembar Evaluasi Tengah Semester Lembar Penilaian Holistik dari Wali Kelas, GPK dan Orang Tua.

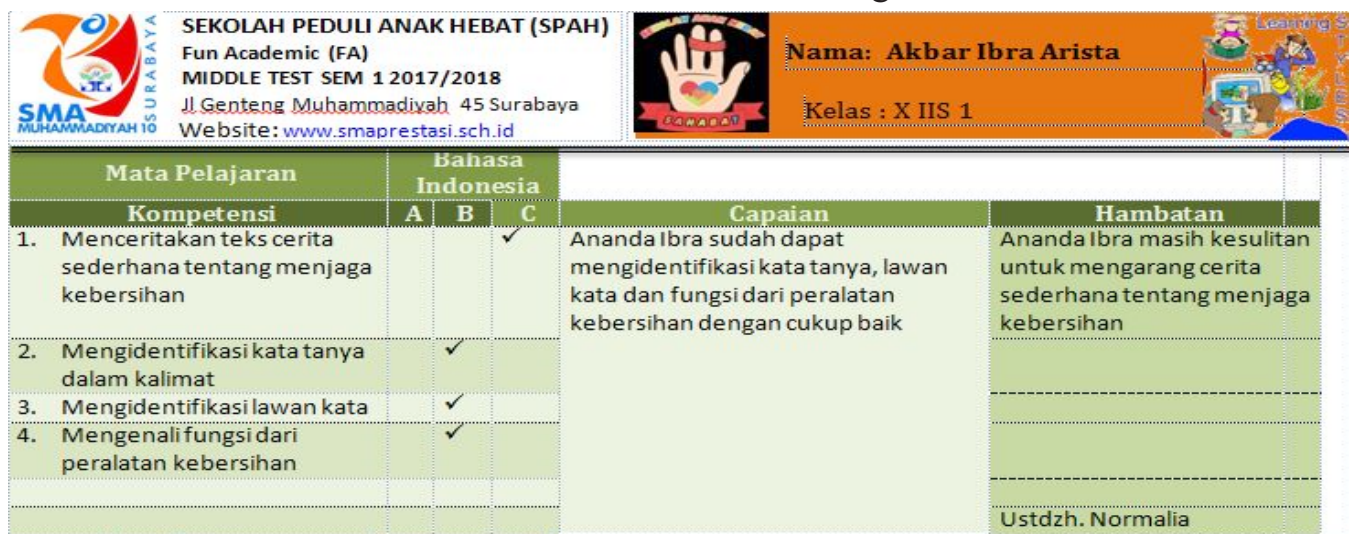

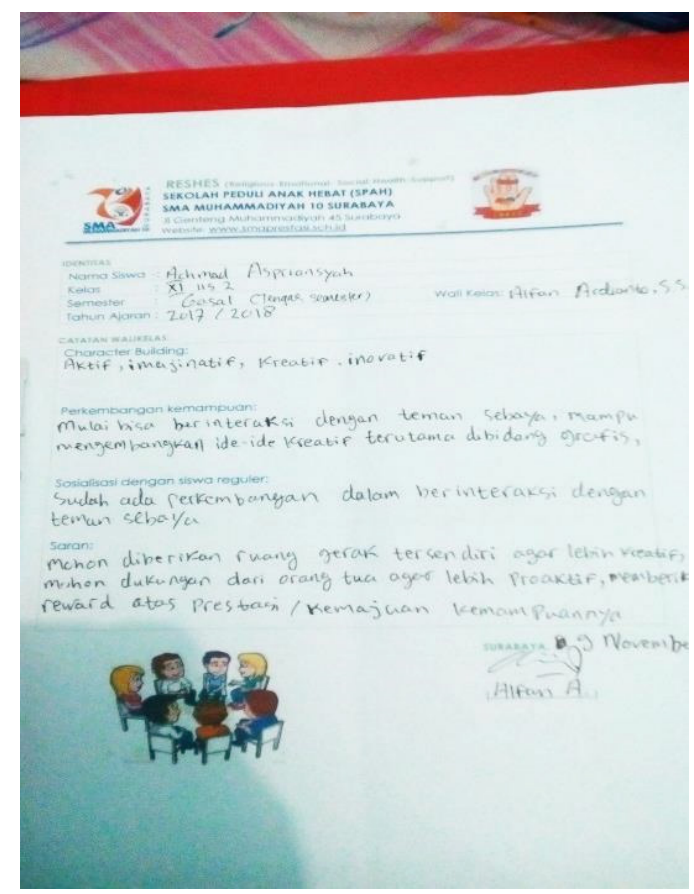




\section{Parent-Society (PS) SPAH}

Faktor terbesar keberhasilan anak hebat terdapat pada peran orang tua dan atau lingkungan keluarga. Oleh karena itu SPAH SMAM X Surabaya berupaya menciptakan lingkungan keluarga yang bersahabat. Orangtua/wali siswa menjadi pendamping dalam pelaksanaan pendidikan inklusi. Robinson-Robinson dalam Smith 2012 menyatakan mereka (orang tua) harus didorong untuk terlibat pada setiap aspek kehidupan sekolah. Mereka harus selalu diberitahu perubahan-perubahan yang terjadi di sekolah yang akan memberikan dampak kepada inklusivitas anak mereka. SPAH mengadakan konsultasi secara formal setiap tiga bulan sekali dengan orang tua dan informal di setiap harinya melalui WA personal dan WA group orang tua SPAH. Mereka juga dapat mengakses perkembangan anak hebat melalui website dan e-learning sekolah. Setiap tahun diadakan parenting keluarga anak hebat yang mana anak-anak hebat dapat menunjukkan performa bakat-minat. Sharing santai antar orang tua dan juga tenaga ahli dengan tema yang dibutuhkan, misalkan tentang layanan pendidikan terkhusus perguruan tinggi yang membuka jurusan untuk anak berkebutuhan khusus, dukungan sosial masyarakat dan bantuan hukum untuk anak penyandang disabilitas. Pendampingan dukungan sosial untuk anak hebat juga dikembangkan oleh SPAH ke masyarakat dengan membuka forum konsultasi bagi masyarakat sekitar yang mempunyai anak berkebutuhan khusus dengan tenaga ahli. Seperti yang telah dilakukan siswa reguler ketika mengkampanyekan Sekolah Anak Hebat pada acara Parade Komunitas Suara Surabaya di taman Munduh (6/8/17).

\section{Refleksi Pelaksanaan Program SPAH}

Dalam pelaksanaan dua tahun terakhir program SPAH telah muncul suasana psikologis yang kondusif bagi anak hebat untuk membangun kepercayaan diri mereka. Banyak diantara anak hebat yang mulai aktif di kegiatan masyarakat seperti karang taruna, takmir masjid, mengikuti berbagai komunitas entrepreneur dengan berjualan produk di mall/pinggir jalan, perform seni musik diberbagai acara dan lomba sesuai passion, lebih mampu mengendalikan emosi, mandiri dalam mengurus diri sendiri dan mengatasi masalah yang dihadapi.

Sementara yang menjadi tantangan dalam pelaksanaan program SPAH adalah mencari kesesuaian metode pembelajaran yang mengikuti passion dan potensi setiap siswa. Semakin banyak anak hebat di SPAH, maka semakin banyak ragam potensi dengan karakteristik berbeda yang harus digali satu-persatu. Hal ini menuntut SPAH untuk terus berkreasi dan berinovasi untuk mencari format pembelajaran individu yang tepat dan bisa mempercepat potensi mereka menjadi prestasi. Suatu pembelajaran yang tepat terlihat ketika anak hebat semangat ke sekolah untuk mencari guru yang memberinya inspirasi dan percaya diri, penuh semangat dalam melakukan aktivitas yang dapat meningkatkan life-skill mereka.

\section{Kesimpulan}

Model pembelajaran SPAH yang dilaksanakan di SMA Muhammadiyah X Surabaya berpijak pada tiga tatanan. Pertama lebih mengembangkan potensi hati daripada potensi akal dengan perbandingan potensi hati, fisik dan akal sebesar 50\% : $30 \%: 20 \%$. Dengan perpaduan potensi hati dan fisik diharapkan anak hebat memiliki karakter yang positif, sehingga dapat kuat 
dan menjalani hidupnya dengan baik. Kedua, kedekatan hati antara guru dan anak hebat adalah yang utama terhadap proses pembelajaran, sehingga tidak diperkenankan memberikan hukuman, tetapi diupayakan untuk memberikan perhatian yang lebih kepada anak didik. Ketiga, adanya fleksibilitas pembelajaran bisa kapanpun (jadwal tidak bersifat kaku) di manapun (belajar tidak harus di dalam kelas, bisa di taman/magang di tempat tertentu) dan memakai media/metode pembelajaran apapun (adanya kebebasan berkreasi bagi guru untuk mengembangkan model pembelajaran yang terpenting anak senang dan dekat dengan guru). Lima model pembelajaran SPAH ini berupaya mewujudkan pendidikan holistik bagi anak hebat (lihat gambar 3).

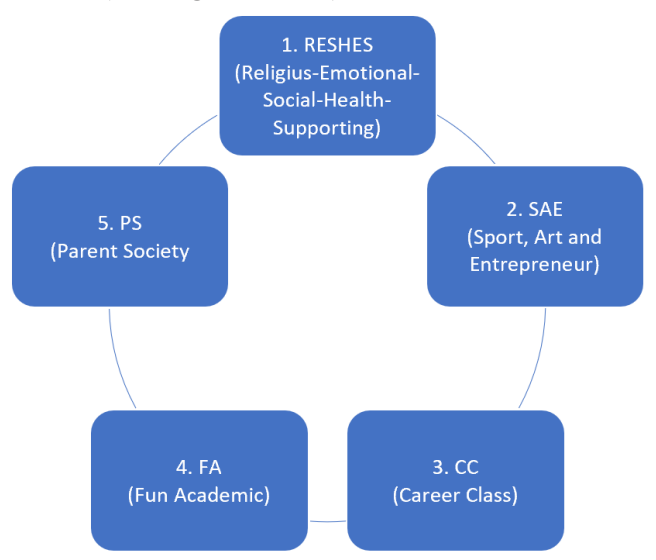

Gambar 4. Siklus Lima Model

Pembelajaran SPAH

Kelima model pembelajaran SPAH ini perlu diaktifkan supaya tercipta suasana pembelajaran yang positif, lingkungan yang mendukung keberhasilan anak hebat dan yang mampu memberikan pemahaman mendalam tentang kebutuhan sosial, emosional dan fisik mereka serta sangat penting pula untuk mengenali, menjaga dan menguatkan bakat-minat setiap anak hebat.

\section{Daftar Rujukan}

Bowman, I. (1986). Teacher Training and the Integration of Handicapped Pupils: Some Findings from a Fourteen Nation UNESCO Study. European Journal of Special Needs Education, 1, pp 29-38.

Center, Y., \& Ward, J. (1987). Teachers' Attitudes towards the Integration of Disable Children into Regular Schools. The Exceptional Child, 34, pp 41-56.

Ford, J.. (2013). Educating Students with learning Disabilities in Inclusive Classrooms. Electronic Journal for Inclusive Education Vol. 3, No.1

Hurlock, E.B. (1990). Psikologi Perkembangan Suatu Pendekatan Sepanjang Rentang Kehidupan. Jakarta: Penerbit Erlangga.

Kalfus, G. R. (1984). Peer-mediated Instruction: A Critical Review. Child Development and Family Behavior Therapy, 6, 17-43.

Konza, D. (2002). Review of Special Educational Services. Engadine, NSW: St John Bosco College.

McLeskey, J. \& Waldron, N. L. (2011). Educational Programs for Elementary Students with Learning Disabilities: Can They be both Effective and Inclusive? Learning Disabilities Research \& Practice, 26, 48-57.

Permendiknas No. 70. (2009). Pendidikan Inklusif bagi Peserta Didik yang memiliki Kelainan dan Memiliki Potensi Kecerdasan dan/atau Bakat Istimewa. Direktorat Pembinaan Pendidikan Khusus dan Layanan Khusus Kementerian Pendidikan dan Kebudayaan.

Schumm, J., \& Vaughn, S. (1992). Plans for Mainstreamed Special Education Students: Perceptions of General 
Education Teachers. Exceptionality, 3(2), pp 81-96.

Smith, J. D. (2012). Konsep dan Penerapan Pembelajaran Sekolah Inklusif. Bandung: Penerbit NUANSA

Vaughn, S., Elbaum, B.E., Schumm, J.S. and Hughes, M.T. (1998). Social Outcomes for Students with and without Learning Disabilities in Inclusive Classrooms. Journal of Learning Disabilities, 31, 428-436.

Westwood, P. \& Graham, L. (2003). Inclusion of Students with Special Needs: Benefits and Obstacles Perceived by Teachers in New South Wales and South Australia. Australian Journal of Learning Disabilities, 8(1), pp 3-15.

Wills, D., \& Jackson, R. (2000). Report Card on Inclusive Education in Australia. Interaction, 14, pp 5-12. 